Vol. 2, No. 2, Juli 2018, 144-152

Available Online at https://ejournal.warmadewa.ac.id/index.php/kulturistik DOI: dx.doi.org/10.22225/kulturistik.2.2.750

\title{
PENERAPAN METODE MIND MAPPING UNTUK MENINGKATKAN KETERAMPILAN MENULIS KARANGAN DESKRIPSI BAHASA INGGRIS PESERTA DIDIK KELAS X AP-1 SMK WIDYA MANDALA BADUNG
}

\author{
I Made Purna Wijaya \\ Universitas Udayana \\ imadepurnawijaya83@gmail.com
}

\begin{abstract}
ABSTRAK
Kajian ini bertujuan untuk mengetahui keterampilan peserta didik kelas X AP 1 SMK Widya Mandala Badung dalam mengarang deskripsi melalui penerapan metode mind mapping berdasarkan tiga masalah. Kajian ini memakai desain Penelitian Tindakan Kelas (PTK) pada kelas X AP 1 SMK Widya Mandala Badung yang berjumlah 27 orang. Kajian ini dilaksanakan dengan dua siklus tindakan yang menggunakan empat tahapan diantaranya, perencanaan, tindakan, observasi dan refleksi. Pengumpulan data melalui pengamatan, catatan lapangan, angket dan tes menulis. Analisis data dipaparkan secara kualitatif dan kuantitatif. Penyajian hasil penelitian ditampilkan dalam tabel dan diagram. Hasil kajian ini menunjukan bahwa analisis data kualitatif dan kuantitatif digunakan sebagai acuan dalam peningkatan keterampilan peserta didik dalam menulis karangan deskripsi. Peningkatan keterampilan peserta didik dapat dilihat dari tingkatan nilai ratarata kelas, yaitu pada tahap tes awal (pra-tindakan) 67,3, pada siklus I menjadi 73,9 dan pada siklus II menjadi 78,3. Peningkatan kemampuan peserta didik juga dibuktikan dengan meningkatnya prosentase ketercapaian jumlah nilai peserta didik dengan nilai $K K M \geq 70$. Dari tes tahap awal (pra-tindakan) prosentase keberhasilan mencapai $33,33 \%$, pada siklus I mencapai $59,26 \%$ dan pada siklus II mengalami peningkatan sebesar $100 \%$.
\end{abstract}

Kata kunci: Mind Mapping, menulis, karangan deskripsi

\begin{abstract}
[Title: The Application of Mind Mapping Method to Improve Writing Skill in Writting English Descriptive Text of Students at Grades X AP-1 SMK Widya Mandala Badungl The aim of this paper is to determine students' writing skill in doing descriptive. The research was conducted in the form of classroom action research, and mind mapping as learning method applied for improving students' writing skill. The application of this method in teaching and learning process are expected to solve the problem that are faced by students at grade X AP1 SMK Widya Mandala. Constructivism theory were used to determine the learning model, in this case it has the same direction with mind mapping method. The theory of grammar and writing theory were used as a reference in making the assessment rubric. Methods of data collection and data analysis techniques performed quantitatively and qualitatively. Data were collected through a method of testing, observatiaon and questionnaires. The quantitative data collected through test and questionnaires, while the qualitative through observation. The result of the data analysis were presented in tables and charts with the description. The increased writing skill of the students can be seen from the average class grade, that is it is 63,7 in the pre-test, in the first cycle it became 73,9 and in the second cycle it became 78,3. The increased writing skill of the students is also proved by the increased percentage of grade achieved by the
\end{abstract}


Vol. 2, No. 2, Juli 2018, 145

Available Online at https://ejournal.warmadewa.ac.id/index.php/kulturistik DOI: dx.doi.org/10.22225/kulturistik.2.2.750

students that is more than 70. In the pre-test, the percentage of grade achieved was $33,33 \%$, in the first cycle it became 59,26\% and in the second cycle it became $100 \%$.

Keywords: Mind Mapping method, writing, descriptive text

\section{PENDAHULUAN}

Bahasa Inggris adalah bahasa yang wajib dikuasai oleh peserta didik untuk mendukung bidang keahlian untuk mencapai kompetensi lulusan dari segi kuantitas maupun kualitas. Melalui penguasaan bahasa Inggris yang baik, mereka diharapkan mampu bersaing dengan ribuan bahkan jutaan pesaing di lapangan kerja. Berdasarkan fenomena tersebut, pembelajaran bahasa Inggris diharapkan berorientasi pada keterampilan (skill), sehingga dapat digunakan di dunia kerja.

Alwasilah menyatakan bahwa pembelajaran menulis adalah pembelajaran yang berdasarkan kemampuan yang diperoleh melalui pengalaman belajar (Alwasilah \& S.S., 2005). Adapun hakikat dari pembelajaran menulis adalah kegiatan membantu peserta didik untuk lebih mendalami berbagai bentuk ekspresi, serta mendorong mereka untuk dapat mengekspresikan diri secara bebas, tepat, serasi, dan penuh percaya diri, sehingga peserta didik merasa bebas dalam mengekspresikan kemampuan dalam menulis. Karangan deskripsi digunakan dalam penelitian ini dalam pembelajaran menulis. Karangan deskripsi dipilih karena bentuk tulisan ini menjelaskan apa yang diamati oleh panca indera. Deskripsi juga dilakukan untuk menjelaskan perasaan penulisnya. Peserta didik dapat menuangkan pikiran melalui tulisan tentang hal yang diamati dan dirasakan ke dalam sebuah karangan deskripsi (Keraf, 1981).

Dalam pembelajaran menulis, peserta didik hendaknya memiliki dorongan yang tinggi. Kenyataannya adalah dorongan bagi peserta didik masih dianggap kurang produktif. Selain itu, peserta didik juga sulit memeroleh ide dalam sebuah karangan. Sulitnya mendapatkan gagasan-gagasan dalam menulis sebuah karangan disebabkan oleh lemahnya kemampuan kosakata yang dimiliki peserta didik tersebut. Sedangkan tingginya kemampuan kosakata yang dimiliki seseorang akan membuat mereka lebih mudah dalam mencurahkan gagasan mereka dalam sebuah karangan (Nunan, 1991).

Permasalahan di atas juga dialami oleh peserta didik kelas X AP-1 SMK Widya Mandala Badung. Dari hasil observasi awal yang dilakukan, belum terlihat secara pasti keberhasilan peserta didik dalam menulis dari segi proses dan peran aktif peserta didik. Hal ini terlihat setelah dilakukan tes menulis karangan deskripsi pada 27 orang peserta didik di kelas X AP-1 SMK Widya Mandala Badung, hanya beberapa peserta didik sesuai dengan ketuntasan. Mengacu pada permasalahan yang terjadi di dalam kelas,pembelajaran menulis melalui penerapan model, metode atau strategi pembelajaran sangat penting sehingga dapat meningkatkan motivasi belajar peserta didik dalam mengekspresikan gagasan dan menuangkannya dalam tulisan (Buzan, 1993, 2002a, 2002b).

Terkait dengan permasalahan peserta didik kelas X AP-1 SMK Widya Mandala Badung, maka dibutuhkan metode pembelajaran yang sesuai sehingga keterampilan menulis meningkat. Sehubungan dengan hal tersebut, dalam penelitian ini digunakan metode pembelajaran mind mapping. Hal ini dilakukan berdasarkan pertimbangan bahwa metode pembelajaran tersebut dikenal sangat baik untuk meningkatkan keterampilan dalam menulis khususnya menulis 
Vol. 2, No. 2, Juli 2018, 146

Available Online at https://ejournal.warmadewa.ac.id/index.php/kulturistik

DOI: dx.doi.org/10.22225/kulturistik.2.2.750

karangan deskripsi. Berdasarkan uraian dalam latar belakang seperti uraian:

1. Bagaimana hasil evaluasi belajar peserta didik kelas X AP-1 SMK Widya Mandala Badung dalam menilai keterampilan menulis karangan deskripsi sebelum menggunakan metode pembelajaran mind mapping?

2. Bagaimana hasil belajar peserta didik kelas X AP-1 SMK Widya Mandala Badung dalam menulis karangan deskripsi setelah menerapkan metode pembelajaran mind mapping?

Penelitian ini bertujuan untuk mendeskripsikan peningkatan keterampilam peserta didik kelas X AP-1 SMK Widya Mandala Badung dalam menulis deskripsi sebelum menggunakan metode pembelajaran mind mapping dan setelah menggunakan metode pembelajaran mind mapping.

\section{METODE}

Penelitian dilakukan di kelas X AP-1 SMK Widya Mandala Badung. Tempat ini dipilih karena berdasarkan hasil observasi kelas dan hasil penilaian dalam menulis karangan deskripsi bahasa Inggris masih relatif rendah. Hasilnya dapat dilihat dari keterampilan menulis peserta didik. Penelitian ini menggunakan dua siklus. Hal ini berarti jika pada siklus pertama hasil penilaian peserta didik belum sesuai dengan target pencapaian yang telah ditentukan, maka peneliti melaksanakan siklus kedua dengan materi pembelajaran sesuai kurikulum dengan menggunakan metode pembelajaran yang sama. Penelitian ini akan dihentikan dan dianggap berhasil apabila nilai peserta didik sudah memenuhi target pencapaian yaitu kriteria ketuntasan minimal (KKM) 70 .

Penelitian ini menggunakan jenis data kualitatif dan data kuantitatif. Arikunto mengatakan bahwa data kualitatif adalah data yang didapatkan dari hasil observasi dan angket, sedangkan data kuantitatif adalah data yang didapatkan dari hasil tes keterampilan membuat karangan deskripsi, baik pada siklus I maupun siklus II (Arikunto, 1996). Instrumen yang dipakai memperlancar pelaksanaan penelitian ini adalah: (1) lembar observasi, (2) angket sederhana, (3) tes, dan (4) catatan peneliti. Data penelitian dikumpulkan melalui beberapa langkah, yaitu: (1) melakukan observasi, (2) menyebarkan kuesioner, dan (3) pemberian tes kemampuan menulis karangan deskripsi. Pengumpulan data disesuaikan dengan hasil pada pra-tindakan, siklus I dan siklus II untuk mengetahui ada atau tidak peningkatan kemampuan peserta didik dalam menulis (Cresswell, 2010).

\section{PEMBAHASAN}

Pada bagian ini dipaparkan hasil penelitian tindakan kelas yang dilakukan pada peserta didik kelas X AP-1 SMK Widya Mandala Badung sebagai subjek penelitian. Data tersebut ditulis sesuai dengan perencanaan sampai pada refleksi berikutnya. Dengan demikian, uraian ini dimulai dari bagaimana menyusun perencanaan, melaksanaan tindakan, observasi/ pengamatan, sampai pada refleksi pra-tindakan, siklus I yang kemudian dilanjutkan pada hal yang sama pada siklus II. 


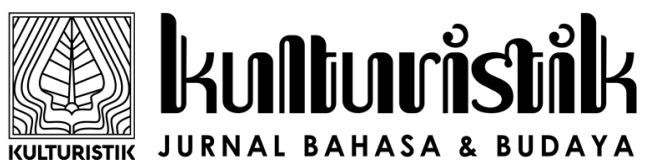

Vol. 2, No. 2, Juli 2018, 147

Available Online at https://ejournal.warmadewa.ac.id/index.php/kulturistik DOI: dx.doi.org/10.22225/kulturistik.2.2.750

\section{Kemampuan Peserta didik dalam Menulis Karangan Deskripsi Sebelum Menerapkan Metode Pembelajaran Mind Mapping sebagai Hasil Penelitian Pra-Tindakan}

Penelitian ini dimulai pada tanggal 16 Agustus 2017, sebagai tahapan awal dilakukan pra-tindakan untuk mendapatkan data awal peserta didik. Penelitian ini dilaksanakan dalam pelaksanaan pembelajaran bahasa Inggris pada peserta didik kelas X AP-1 SMK Widya Mandala Badung setiap hari Rabu pukul 07.30 witasampai 09.30 wita.Yang diawali dengan penyebaran angket yang diberikan kepada seluruh peserta didik kelas X AP-1 SMK Widya Mandala Badung dengan jumlah soal sebanyak sepuluh butir kuesioner dalam bentuk pilihan ganda.Dari kuesioner tersebut diketahui bahwa respons peserta didik dalam pembelajaran menulis karangan deskripsi bahasa Inggris masih sangat kurang. Di samping itu, tingkat minat dan kemampuan mereka masih kurang dalam menulis karangan deskripsi. Setelah penyebaran angket dilanjutkan dengan pemberian tes menulis karangan deskripsi.

Berdasarkan data hasil tes kemampuan peserta didik, diketahui bahwa ratarata keterampilan menulis peserta didik sebesar $67,4,18$ peserta didik $(66,67 \%)$ dengan nilai terendah 57 dan 9 peserta didik (33,33\%)nilai tertinggi 83 sesuai kriteria ketuntasan minimal (KKM) yang ditetapkan.

\section{Kemampuan Peserta Didik dalam Menulis Karangan Deskripsi Setelah Menerapkan Metode Pembelajaran Mind Mapping sebagai Hasil Tindakan pada Siklus I dan Siklus II \\ Pelaksanaan Penelitian Tindakan Kelas Siklus I}

Pelaksanaan kegiatan penelitian tindakan kelas pada siklus I dilaksanakan selama tiga kali pertemuan. Pertemuan pertama dimulai pada hari Rabu, 30 Agustus 2017 Jam pembelajaran Bahasa Inggris pada peserta didik kelas X AP-1 SMK Widya Mandala Badung berlangsung pada jam pelajaran kepertama yaitu pada pukul 07.30 WITA sampai 09.30 WITA. Pada tahap kegiatan ini pembelajaran guru diawali dengan membagikan dan menjelaskan hasil karangan peserta didik yang dikerjakan pada tahap pra-tindakan. Kemudian guru menampilkan kriteria penilaian menulis karangan deskripsi berupa rubrik pada slide powerpoint di layar, untuk memeriksa karangan peserta didik dengan skor yang diperoleh berdasarkan kriteria penilaian menulis karangan deskripsi yang ditampilkan pada layar.

Pelaksanaan kegiatan penelitian tindakan kelas pada pertemuan kedua, Rabu, tanggal 6 September 2017. Pembelajaran Bahasa Inggris berlangsung pada jam pelajaran kepertama yaitu pada pukul 07.30 WITA sampai 09.30 WITA. Sama halnya dengan pertemuan kepertama, pelaksanaan pembelajaran diawali dengan mengucapkan salam, mengabsensi kehadiran peserta didik, melakukan apersepsi dan motivasi. Kegiatan inti pembelajaran diawali dengan diskusi mengenai struktur generik karangan deskripsi, ciri kebahasaan karangan deskripsi, seperti: penggunaan artikel, konjungsi, preposisi, penggunaan kata ganti, dan penggunaan tense. Disamping itu, peserta didik juga diberikan waktu untuk bertanya mengenai tata cara membuat draf karangan dengan menggunakan metode mind mapping.

Proses belajar mengajar berlanjut dengan menugasi peserta didik untuk mengembangkan draf karangan yang sudah dibuat menjadi karangan deskripsi 
berdasarkan urutan berpikir pada draf karangan. Guru memberikan waktu tiga puluh menit untuk menyelesaikan karangan mereka. Selama kegiatan menulis berlangsung, guru memantau kegiatan peserta didik. Setelah tiga puluh menit berlalu, guru meminta peserta didik berhenti menulis dan meletakkan alat tulis di atas meja. Selanjutnya, guru menampilkan konsep metode pembelajaran mind mapping yang sudah dijelaskan sebelumnya. Langkah terakhir dalam pelaksanaan metode mind mapping adalah melakukan presentasi. Tiap-tiap anggota kelompok memiliki kesempatan yang sama untuk bisa mempresentasikan karangan di depan kelas.

Pertemuan ketiga dilaksanakan pada hari Rabu, 13 September 2017 dan pelaksanaan jam pelajarannya berlangsung pada jam pertama, yaitu pukul 07.30 WITA sampai dengan 09.30 WITA. Pada pertemuan ini kegiatan pembelajaran dilakukan dengan memberikan tes menulis karangan deskripsi kepada peserta didik. Pertemuan ini merupakan pertemuan terakhir pada siklus I, yaitu guru memberikan tes menulis karangan deskripsi dan membagikan angket untuk melihat peningkatan kemampuan peserta didik setelah diterapkan metode pembelajaran mind mapping.

Berdasarkan hasil angket pada siklus I dapat dijelaskan bahwa peserta didik memberikan respon baik terhadap mata pelajaran menulis karangan deskripsi melalui penerapan metode mind mapping. Keinginan belajar dan keterampilan peserta didik dalam mengelompokkan dan memaparkan ide sesuai struktur generik mengarang nampak meningkat, demikian pula keterampilan peserta didik dalam penggunaan kosakata dan bahasa berlandaskan gramatika.

Berdasarkan hasil analisis tes keterampilan menulis peserta didik yang dijelaskan pada Tabel 4.14 seperti tersebut di atas, diperoleh nilai rata-rata 73,8. Apabila dibandingkan pada tahap pra-tindakan sebesar 67,4, maka keterampilan pada tahap I mengalami peningkatan sebesar $6,4 \%$, dengan nilai tertinggi 88 , sedangkan nilai terendah adalah sebesar 65 . Peserta didik yang belum mencapai nilai kompetensi sebanyak 11 orang $(40,73 \%)$. Hal ini berarti bahwa baru hanya 16 orang $(59,7 \%)$ peserta didik yang sudah mencapai nilai sesuai dengan nilai ketuntasan sebesar $\geq 70$. Nilai pada siklus I juga mengalami keterampilan mengarang deskripsi.

\section{Pelaksanaan Penelitian Tindakan Kelas Siklus II}

Pelaksanaan penelitian siklus II dilakukan dalam dua kali pertemuan. Pertemuan I dilaksanakan pada hari Rabu, 20 September 2017 dan pertemuan II hari Rabu, 27 September 2017 pada jam yang sama seperti pada siklus I, yaitu pukul 07.30 WITA sampai 09.30 WITA. Inti dari kegiatan pertemuan pertama siklus II adalah meningkatkan kemampuan berpikir peserta didik dalam kegiatan menulis karangan deskripsi melalui penjelasan materi, pemberian contoh kasus, melakukan diskusi pemecahan masalah pada kasus yang terjadi, melakukan editing dan revisi, serta melakukan presentasi untuk menanamkan kesiapan dan percaya diri peserta didik terhadap hasil tulisan yang dibuat.

Pengamatan tidak hanya dilakukan pada kegiatan pembelajaran, seperti menulis lembar pengamatan dan mencatat kegiatan pendidik dan peserta didik, tetapi observasi dilaksanakan dengan membagikan kuesioner kepada peserta 
Vol. 2, No. 2, Juli 2018, 149

Available Online at https://ejournal.warmadewa.ac.id/index.php/kulturistik DOI: dx.doi.org/10.22225/kulturistik.2.2.750

didik. Pengisian kuesioner oleh peserta didik ini sama seperti pengisian angket pada siklus I, yaitu butir pernyataan sebanyak sepuluh butir dengan pilihan a, b, c, dan d. Peserta didik diberikan waktu sepuluh menit untuk menjawab butir-butir pernyataan tersebut. Berdasarkan jawaban tersebut dapat diketahui pada umumnya peserta didik memberikan respon yang positif terhadap metode mind mapping dalam pembelajaran menulis deskripsi. Dari sepuluh butir angket yang disebarkan kepada peserta didik, hampir seluruhnya dari mereka memilih pernyataan setuju dan sangat setuju. Hal ini berarti bahwa minat belajar mereka terhadap pembelajaran mind mapping dalam pembelajaran menulis karangan deskripsi meningkat. Di samping itu, mereka lebih percaya diri atas kemampuan menulis yang dimiliki baik dari aspek isi dan ide, pengorganisasian karangan, penggunaan kosakata, maupun mekanik.

Perolehan nilai rata-rata atas keterampilan peserta didik dalam mengarang deskripsi pada siklus II sebesar 78,3. Keterampilan tersebut berbeda jauh dengan perolehan nilai rata-rata kelas atau keterampilan peserta didik dalam menulis karangan deskripsi pada siklus I sebesar 73,8 . Perbedaan ini menandakan bahwa sudah terjadi peningkatan secara signifikan kemampuan peserta didik dalam menulis karangan sebesar 4,5.

Adapun nilai peserta didik terendah pada siklus II ini sebesar 70, sedangkan nilai tertinggi sebesar 90 , tidak ada memeroleh nilai $\geq 70$ yang berarti ketuntasan secara klasikal sudah mencapai $100 \%$. Prosentase ketuntasan peserta didik secara klasikal sudah melampaui target yang ditetapkan dalam pelaksanaan penelitian tindakan kelas ini.

Perbandingan Nilai Rata-Rata Kelas Berdasarkan Aspek Penilaian Menulis Karangan Deskripsi

\begin{tabular}{clccc}
\hline No. & \multicolumn{1}{c}{ Aspek Penilaian } & $\begin{array}{c}\text { Rata-Rata Pra- } \\
\text { Tindakan }\end{array}$ & $\begin{array}{c}\text { Rata-Rata } \\
\text { Siklus I }\end{array}$ & $\begin{array}{c}\text { Rata-Rata } \\
\text { Siklus II }\end{array}$ \\
\hline 1. & Aspek ide dan isi & 18,6 & 20,3 & 21,9 \\
2. & Aspek organisasi & 14,1 & 16,1 & 16,6 \\
3. & Aspek penggunaan bahasa & 16,3 & 17,9 & 18,9 \\
4. & Aspek penggunaan kosakata & 14,1 & 15,3 & 16,4 \\
5. & Aspek mekanik & 4,2 & 4,3 & 4,5 \\
& & 67,3 & 73,9 & 78,3 \\
\hline
\end{tabular}

Pada tabel seperti uraian tersebut di atas terlihat bahwa nilai menulis karangan deskripsi mengalami peningkatan dari pra-tindakan menuju siklus I, demikian pula siklus II mengalami peningkatan dari nilai siklus I. Untuk lebih jelas, perbandingan nilai rata-rata kelas tersebut disajikan dalam diagram sebagai berikut. 


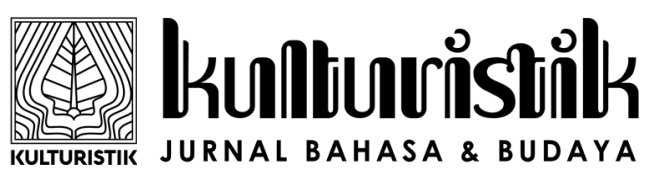

Vol. 2, No. 2, Juli 2018, 150

Available Online at https://ejournal.warmadewa.ac.id/index.php/kulturistik

DOI: dx.doi.org/10.22225/kulturistik.2.2.750

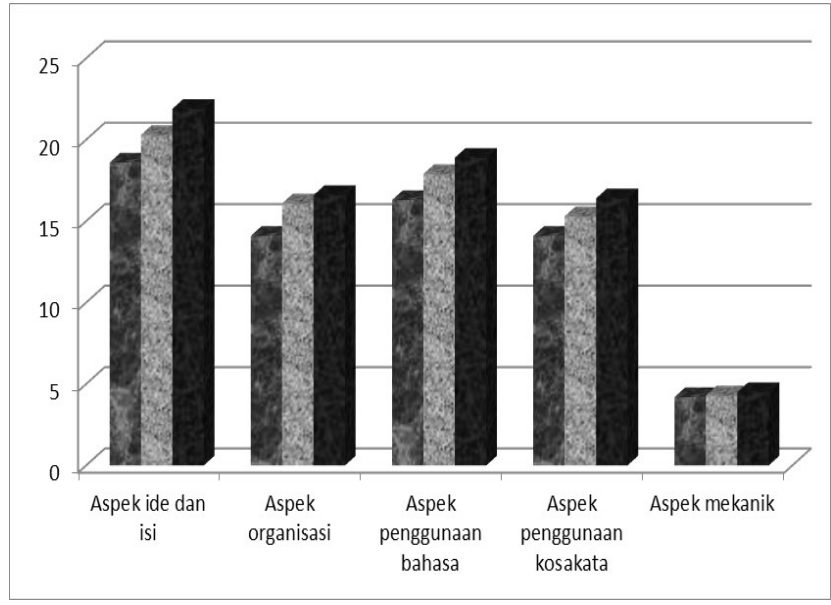

Diagram 1. Perbandingan Nilai Rata-Rata Kelas Tahap Pra-Tindakan, Siklus I, dan Siklus II Berdasarkan Aspek Penilaian Menulis Karangan Deskripsi

Berdasarkan data analisis perbandingan nilai rata-rata kelas tahap pratindakan, siklus I, dan siklus II pada tabel dan diagram di atas, dapat diketahui peningkatan nilai rata-rata peserta didik dalam satu kelas pada setiap siklus yang disajikan dalam diagram berikut ini.

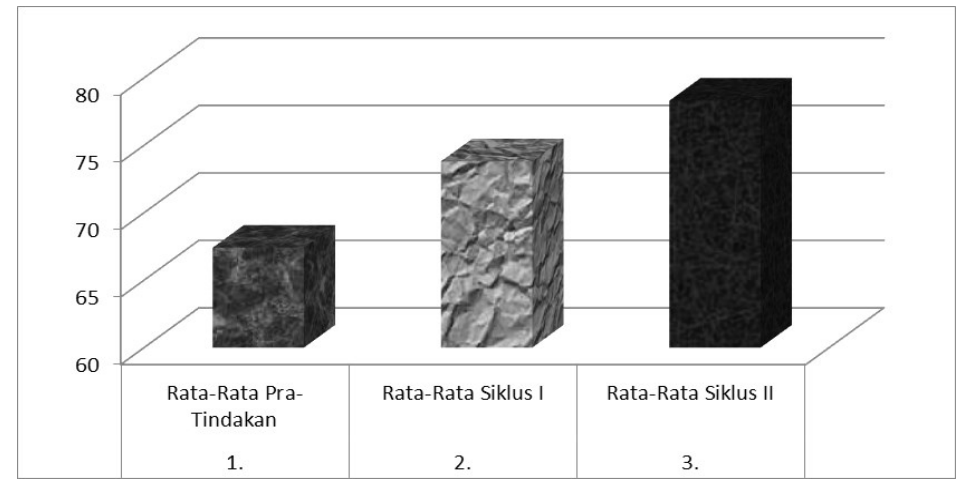

Diagram 2. Perbandingan Nilai Rata-Rata Kelas Tahap Pra-Tindakan, Siklus I, dan Siklus II

Prosentase Peningkatan Keberhasilan Peserta didik Mencapai Nilai $\mathrm{KKM} \geq 70$

\begin{tabular}{llcc}
\hline No. & Pelaksanaan Tindakan & $\begin{array}{c}\text { Peserta didik yang } \\
\text { Mencapai Nilai KKM } \geq \mathbf{7 0}\end{array}$ & Prosentase \\
\hline 1. & Pra-Tindakan & 9 & $33,33 \%$ \\
2. & Siklus I & 16 & $59,26 \%$ \\
3. & Siklus II & 27 & $100 \%$ \\
\hline
\end{tabular}


Vol. 2, No. 2, Juli 2018, 151

Available Online at https://ejournal.warmadewa.ac.id/index.php/kulturistik DOI: dx.doi.org/10.22225/kulturistik.2.2.750

Pada tabel di atas nampak jelas bahwa pada tahap pra-tindakan prosentase dalam pembelajaran menulis karangan deskripsi adalah sebesar 33,33\% atau sebanyak 9 dari 27 orang. Pada siklus I prosentase kriteria ketuntasan minimal $(\mathrm{KKM}) \geq 70$ dalam pembelajaran menulis karangan deskripsi adalah sebesar $59,26 \%$ atau sebanyak 16 dari 27 orang peserta didik. Demikian pula pada siklus II, jumlah yang mencapai nilai $\geq 70$ dalam menulis karangan deskripsi sudah mencapai $100 \%$ yang berarti bahwa semua mencapai nilai ketuntasan. Hal itu menunjukkan peningkatan prosentase jumlah peserta didik dari tahap pratindakan ke tahap I sebesar 25,93\%, dan dari tahap I ke tahap II sebesar $40,74 \%$. Untuk lebih jelas, berikut ini disajikan diagram prosentase peningkatan keberhasilan peserta didik mencapai nilai $\mathrm{KKM} \geq 70$ berdasarkan kriteria keberhasilan tindakan.

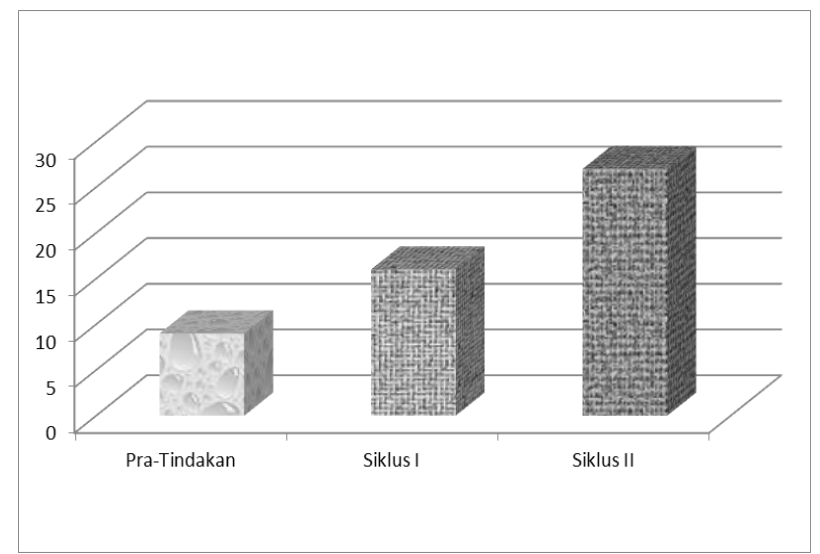

Diagram 3. Prosentase Peningkatan Keberhasilan Peserta didik Mencapai Nilai $\mathrm{KKM} \geq 70$

Berdasarkan diagram di atas, dapat disimpulkan bahwa prosentase keberhasilan sudah melampaui target keberhasilan pelaksanaan penelitian dari tahap pra-tindakan, tahap I dan tahap II sudah melampaui target khususnya pada siklus II, yaitu $85 \%$ dari jumlah peserta didik yang menjadi subjek penelitian. Jadi penelitian tindakan kelas sampai pada siklus II sudah berhasil dilaksanakan.

\section{SIMPULAN}

Sesuai hasil dan pembahasan dapat dibuat beberapa simpulan, diantaranya,Sesuai hasil analisis data kualitatif dan kuantitatif dapat diketahui bahwa hasil evaluasi belajar peserta didik kelas X AP-1 SMK Widya Mandala Badung dalam mata pelajaran menulis karangan deskripsi sebelum menerapkan metode mind mapping masih tergolong rendah. Kurangnya minat belajar dan keterampilan peserta didik dalam menulis karangan deskripsi juga diperkuat oleh data hasil pengamatan kuantitatif yang berupa tes menulis karangan deskripsi yang dilakukan pada tahap pra-tindakan.

Ada peningkatan hasil belajar peserta didik kelas X AP-1 SMK Widya Mandala Badung pada siklus I dan siklus II dalam menulis karangan deskripsi setelah menerapkan metode mind mapping. Pada siklus I terjadi peningkatan hasil 


\section{(6unlturisistink \\ KULTURISTIK JURNAL BAHASA \& BUDAYA}

Vol. 2, No. 2, Juli 2018, 152

Available Online at https://ejournal.warmadewa.ac.id/index.php/kulturistik

DOI: dx.doi.org/10.22225/kulturistik.2.2.750

menulis karangan deskripsi peserta didik. Peningkatan kemudian berlanjut pada hasil tes keterampilan menulis karangan deskripsi pada akhir siklus II, di mana semua peserta didik yang berjumlah 27 orang peserta didik atau $100 \%$ sudah mendapatkan nilai sesuai dengan kriteria ketuntasan minimal $(\mathrm{KKM}) \geq 70$.

\section{DAFTAR PUSTAKA}

Alwasilah, A. C., \& S.S., A. (2005). Pokoknya Menulis. Bandung: PT Kiblat Buku Utama.

Arikunto, S. (1996). Prosedur Penelitian Suatu Pendekatan Praktek. (PT Rineka Cipta, Ed.). Jakarta.

Buzan, T. (1993). The Mind Map Book. London: BBC Books.

Buzan, T. (2002a). Memahami Peta Pikiran: The Mind Map Book. Batam: Interaksa Batam.

Buzan, T. (2002b). Mind Map: Untuk Meningkatkan Kreativitas. Jakarta: Gramedia Pustaka Utama.

Cresswell, J. W. (2010). Research design: Quantitative, qualitative, and mixedmethod approaches (2nd Editio). Thousand Oaks, CA: Sage.

Keraf, G. (1981). Eksposisi dan Deskripsi. Ende: Nusa Indah.

Nunan, D. (1991). Language Teaching Methodology: A textbook for Teachers. Sydney: Prentice Hall International (UK) Ltd. 